\title{
The Role of Indonesian Constitutional Court in Resolving Disputes among the State Organs
}

\author{
Iwan Satriawan ${ }^{*}$, Khairil Azmin Mokhtar ${ }^{2}$ \\ ${ }^{1}$ Faculty of Law, Universitas Muhammadiyah Yogyakarta, Indonesia. \\ 2 Ahmad Ibrahim Kulliyyah of Law, International Islamic University Malaysia, Malaysia. \\ * Corresponding author's e-mail: iwansatriawan@umy.ac.id
}

\author{
ARTICLE INFO \\ Keywords: \\ Democracy; Constitutional \\ Court; Dispute; State \\ Organ; Jurisdiction \\ How to cite: \\ Satriawan, I., and Mokhtar, \\ K. A. (2019). "The Role of \\ Indonesian Constitutional \\ Court in Resolving Disputes \\ among the State Organs." \\ Hasanuddin Law Review, \\ 5(2): 159-179 \\ DOI: \\ 10.20956/halrev.v5i2.1669
}

\begin{abstract}
The paper attempts to assess the role of the Constitutional Court of Indonesia in the process of consolidating democracy in the country. Examinations are made on the court's decisions regarding dispute concerning jurisdiction among state organs. This paper argues that the Constitutional Court has not made a significant impact on the promotion of democracy. It is believed that the failure of the Court to consolidate democracy through its decisions regarding dispute concerning jurisdiction among state organs could be attributed to two main reasons. The first is due to the unclear concept of subjectum litis of the petitioners to have legal standing in the Constitutional Court, and the second is the lack of understanding of the subject matter jurisdiction of the Court. Due to uncertainties only, small numbers cases registered and heard by the Constitutional Court. Furthermore, most of the cases registered in the Court either been rejected or not been accepted by the judges. Despite the misgivings, the Court is still relevant and have certain contributions towards democracy. It has to a certain extent that enhances the working of checks and balances mechanisms among state organs. It is believed that the court could be more reliable and enhance its function in promoting democracy in the country by defining clearly classification of the subjectum litis as well as the objectum litis of the dispute that it may hear.
\end{abstract}

Copyright (C) 2019 HALREV. All rights reserved.

\section{Introduction}

This paper is an attempt to evaluate the role of the Indonesian Constitutional Court in consolidating democracy through its decisions of the settlement of disputes concerning jurisdiction among state organs. To achieve this purpose, examination of its decisions shall be made. Since 2003 to 2013, twenty-four cases on disputes of authority among state organs had been registered at the Constitutional Court. The Court has decided twenty- 
three of the cases, and a case was ongoing at that time. ${ }^{1}$ The Constitutional Court decided to comply with the petition of one case, three cases were rejected, fifteen cases could not be accepted by the court and four petitions had been withdrew by the applicants.

Initially in this writing some major decisions in the area of disputes concerning jurisdiction among state organs are summarized. This is followed by some achievements made by the Constitutional Court which are considered to have contribution in consolidating democracy in Indonesia, are made. A few obstacles and problems shall be highlighted towards the end followed by some recommendations.

\section{The Constitutional Court: Power and Duties}

The Constitutional Court of Indonesia is a new state organ in Indonesian constitutional system as a result of the amendment of the 1945 Constitution. As an organ of constitution, the Court was designed to be the guardian of the Constitution as well as the sole interpreter of the Constitution. In conducting its constitutional duty, the Constitutional Court aims to uphold its institutional vision: Upholding Constitution in order to realize the rule of law state and democracy in the light of creating a civilized national life.

The existence of the Constitutional Court has completed the judicial power, where previously that the implementing agencies of judicial power in Indonesia was only held by the Supreme Court. ${ }^{2}$ Based on the historical record of the founder, the existence of the court is influenced by South Korean Constitutional Court models very much. Most of the authority of Korean Constitutional Court is adopted in the judicial authority model of the Indonesian constitution. ${ }^{3}$

The Indonesian Constitutional Court is an organ which was established after reform era. The Court has four functions, namely as the guardian of the constitution, the sole interpreter of the constitution, the enforcer of the constitution and the guardian of human rights. The four functions of the Constitutional Court are as stated in article 24C (1) the 1945 Constitution:

1. To review the law against the 1945 Constitution;

2. To decide authoritative dispute among state organ which the authorities given by the 1945 Constitution;

3. To decide dissolution of political parties; and

4. To decide dispute over the result of election.

In addition to the above functions, the Constitutional Court has an obligation to give decision on the opinion of the Dewan Perwakilan Rakyat (the DPR) whether a president and/or vice president have committed crimes, misdemeanors, or does not fulfill the requirements of being president and/or vice president as stated in the 1945 Constitution.

As the guardian of the Constitution, the existence of the Court is to uphold the principle of checks and balances in Indonesian political system. In the concept of separation of powers, the principle of checks and balances between the authorities is considered as the

1 Indonesian Constitutional Court, Rekapitulasi Perkara Sengketa Kewenangan Lembaga Negara. Available from: https://mkri.id/index.php?page=web.RekapSKLN. [Accessed: 7 March 2013].

2 Janpatar Simamore, (2015). "Comparison of Constitutional Court Authority Between Indonesia and South Korea". Jurnal Dinamika Hukum, 15(3): 331-332

3 Ibid. 
essential and fundamental aspect. Constitutionalism means that the principle of separation of powers aims to limit the power of a state, so it is expected to avoid the domination of one power over another one, to avoid subjection and any arbitrary action by the authorities. 4 To deal with that issue, the Constitutional Court has the authority to settle any disputes on constitutional cases.

In the opinion of $\mathrm{Ni}^{\prime}$ matul Huda5, it is common to encounter disputes between a state institution with another one, or between a state institution with a state commission, or between a local government with a central government. In the history of Indonesian constitution prior to the third amendment of the 1945 Constitution, there were no rules regarding the mechanism for resolving disputes over authority between state institutions. During that period, there was no precedent in the Indonesian constitutional practice regarding the settlement of disputes over authority between state institutions whose have authorities given by the constitution. It was only after the third amendment of the 1945 Constitution which adopted the establishment of a state institution of the Constitutional Court whose given an authority by the constitution to decide on an authority dispute between state institutions.

The Constitutional Court is a separate court and does not form part of the hierarchy of ordinary courts. At the apex of hierarchy of ordinary court is the Supreme Court. The Constitutional Court is independent of and equal to the Supreme Court. Such new state government system is a system which basic ideas are intended to make Indonesia into a democratic constitutional state, as reflected in the provisions of Article 1 paragraph [2] and paragraph [3] of the 1945 Constitution. ${ }^{6}$

The establishment of the Constitutional Court has drawn few positive responds as well as adverse comments from constitutional law experts. Some experts hoped that as an independent body, the Constitutional Court will have good impact on the working of state organs. There have been many abuses of power by state apparatus which cause the misconception that Indonesia is not based on rule of law. The newly established Constitutional Court is expected to safeguard the implementation of democracy based on the constitution. ${ }^{7}$

Within a few years of the establishment of the Court, it was mandated to exercise one more function, that was to decide disputes over the results of local election. Such cases were previously handled by the Supreme Court. However, based on article $236 \mathrm{C}$ Local Government Act 2008, it is stated that authority of deciding disputes over the results of local election is moved from the Supreme Court to the Constitutional Court. 8

Benny K. Harman ${ }^{9}$ asserted that the Constitutional Court has provided fresh air to the political life, democracy and national life of Indonesians. The role of the Constitutional

4 Anna Trianingsih and Nuzul Qur'aini Mardiya, (2017). “An Analysis of Subjectum Litis and Objectum Litis on Dispute about the Authority of State Institution from the Verdicts of the Constitutional Court". Constitutional Review, 3(2): 233

5 Ni'matul Huda. (2017). "Potensi Sengketa Kewenangan Lembaga Negara dan Penyelesaiannya di Mahkamah Konstitusi". JH Ius Quia Iustum, 24(2): 194-195

6 Luthfi Widagdo Eddyono. (2018). "The Constitutional Court and Consolidation of Democracy in Indonesia". Jurnal Konstitusi, 15(1): 9

7 Lutu Dwi Prastanta. (2011). “Mahkamah Konstitusi dan Prinsip Judicial Independence dalam Sengketa Antar Lembaga Negara". Jurnal Konstitusi, 4(2): 9

8 Bambang Sutiyoso. (2009). Tata Cara Penyelesaian Sengketa di Lingkungan Mahkamah Konstitusi. Yogyakarta: UII Press, p.6

9 Benny K. Harman. Peranan Mahkamah Konstitusi dalam Reformasi Hukum dari buku Menjaga Denyut Nadi Konstitusi: Refleksi Satu Tahun Mahkamah Konstitusi. Jakarta: Konstitusi Press, p.39 
Court is exercised through checks and balances mechanism in the constitutional system. This mechanism may also overcome gap between lack of sense of justice in society and the practice of authoritarian regime and abuse of power in the level of state for long time, more over in Soeharto regime.

Lindsey argues that the Constitutional Court, if it is effective, has radically potential role to transform relation between judiciary and legislative organ in Indonesia. This also may give a new mechanism of monitoring on behavior of the members of parliament as well as the president. 10

Other issue is the emergence of some state organs and state auxiliary organs which also implies disputes on jurisdiction among state organs and state auxiliary organs. ${ }^{11}$ In relation to this, the Constitutional Court has also jurisdiction to settle disputes concerning jurisdiction among state organs. Evaluation in this writing covers a critical analysis on the achievements as well as the obstacles faced by the Constitutional Court in settling dispute concerning jurisdiction among state organs.

\section{Major Decisions in the area of Disputes concerning Jurisdiction among State Organs}

After the 1998 political reform and amendment of Constitution, many new states auxiliary organ were established in Indonesia. These state auxiliary organs include independent state agencies such as Judicial Commission (KY), Election Commission and Anti-Corruption Commission (KPK) and also part of executive branch such as Ombudsman Commission, National Police Commission, and Broadcasting Commission. ${ }^{12}$ One of implications of the establishment of the new state agencies is overlapping duties between the state auxiliary organs and the existing state organs, and between state auxiliary organ and state auxiliary organ. There is no clear coordination among the state auxiliary organs and the state organs. As a result, disputes concerning authority among state organs as well as the state agencies arisen. Selected decisions of the Constitutional Court which are selected from 23 cases that has been decided by the Constitutional Court.

The decisions of the Constitutional Court in settling disputes concerning authority among state organs could be classified into four categories namely decisions rejected because the issue of the failure of the petitioners to prove the petitum or the petition are "obscure libel" 13, decisions not accepted because the issue of subjectum litis 14 , the decisions not accepted because the issue of objectum litis ${ }^{15}$, and the decision which been

10 See also Butt, Simon and Tim Lindsey. (2009). The People's Prosperity? Indonesian Constitutional Interpretation, Economic Reform, and Globalization, in John Gillespie \& Randall Peerenboom (Eds), Regulation in Asia-Pushing Back on Globalization, London and New York: Routledge. See also Hazama. (2009). Constitutional Review and Democratic Consolidation: A Literature Review. A Paper presented at IDE Discussion Paper, Japan.

11 Zainal Arifin Mochtar. (2012). Penataan Lembaga Negara Independen Setelah Perubahan Undang-Undang Dasar 1945. A summary of Ph.D Thesis. Universitas Gadjah Mada, p.3

12 Zainal Arifin Mochtar. n.10, p.3

13 See Decision No. 06/SKLN-II/2004 and Decision No. 2/SKLN-X/2012

14 Se Decision No. 1/SKLN-X/2012, Decision No. 5/SKLN-V/2011, Decision No. 4/SKLN-IV/2011, Decision No. 26/SKLN-V/2007, Decision No. 030/SKLN-IV/2006, and Decision No. 002/SKLNIV/2006.

15 See Decision No. 3/SKLN-XI/2013, Decision No. 1/SKLN-IX/2011, Decision No. 2/SKLN-IX/2011, Decision No. 1/SKLN-VIII/2010, Decision No. 26/ SKLN-V/2007, Decision No. 004/SKLN-IV/2006, DecisionNo. 027/SKLN-IV/2006. 
accepted by the Court ${ }^{16}$. Zainal argued that there are small numbers of decisions made by the Constitutional Court which are considered giving positive influence on the working of democratic consolidation in relation to disputes on jurisdiction among state organs. These are the decisions are as follows:

\subsection{Rejected decisions}

3.1.1. Decision No. 2/SKLN-X/2012 on Dispute of Authority between President of Republic of Indonesia, Minister of Law and Human Rights and Minister of Finance vs the DPR of Republic of Indonesia and the BPK of Republic of Indonesia

The main issue is whether the buying of $7 \%$ diverting shareholding of PT. Newmont Nusa Tenggara (PT. NNT) in 2010 is the constitutional right of the President in implementation of constitutional mandate without approval of DPR and BPK. However, it is compulsory to ask approval of the DPR in buying of shareholdings divestment of the PT. NNT in 2010 is considered as dilution of supervision function of the DPR and threaten the principle of separation of powers as stated in the 1945 Constitution. The object of dispute is the applicant (The President and the Ministers) argues that they have authority to buy $7 \%$ of shareholdings of divesting of PT. NNT. Approval of the DPR in this case has been considered by the applicant as an obstruction to perform its authority.

The Constitutional Court decided to reject the petition of the applicant. The Court considered that although buying of $7 \%$ of diverting shareholding of PT. NNT by the President is within the constitutional authority of the applicant as the executive branch of the country. the applicant must fulfil some requirements such as (i) approval of DPR either through National Budget Proposal mechanism or specific approval, (ii) the mechanism has to be conducted transparently and responsibly for the sake of people's prosperity, (iii) the program is under supervision of the DPR. Since the buying of $7 \%$ diverting shareholding of PT. NNT by the President was not listed specifically in the National Budget Proposal and did not have yet approval from the DPR, the Constitutional Court stated that the petition of the applicant is legally baseless and therefore it is rejected.

Based on the decision, it can be noted that the Constitutional Court has given its contribution in keeping balance of powers between the President and the DPR. In this case, the Court argues that approval of the DPR is compulsory because it is kind of checks and balances mechanism that must be prevailed in the constitutional democratic state. ${ }^{17}$ In other words, through this decision, the Constitutional Court has given its role in consolidating democracy in Indonesia through guaranteeing the working of checks and balances mechanism between the executive branch and legislature.

3.1.2. Decision No. 068/SKLN-II/2004 on Disputes concerning Authority between Regional Representative Council (DPD) and the President of Republic of Indonesia

Here the petitioner argued that the President had ignored its authority in the process of appointing of members of State Budget Audit (BPK) 2004-2009 and of retiring the members of the State Budget Audit 1999-2004. They further argued

16 See Decision No. 3/SKLN-X/2012.

17 Fatkhurrohman. (2004). Memahami Keberadaan Mahkamah Konstitusi di Indonesia. PT Citra Aditya Bakti, p.36 
that the President must ask consideration of the DPD in appointing and retiring the members of the BPK as stated in the article $23 \mathrm{~F}$ (1) of the 1945 Constitution. The Constitutional Court rejected the petition of the DPD because the DPD failed to prove their argument. The Court argued that the President had not ignored the authority of the DPD in the process of appointing new members of the BPK 20042009 because at the time of process, the DPD had not been existed yet. The Court also further argued that the President has authority to proceed the process without involving the DPD because the law of the BPK had not enacted yet. Therefore, the President used other mechanism as stated by Article 1 of Transitional Provision of the 1945 Constitution which states that the prior institution and regulation still exist up to the enactment and establishment of the new regulation and institution

\subsection{Accepted decisions}

3.2.1. Decision No. 3/SKLN-X/2012 on dispute on authority between Election Commission vs the DPRD Papua and Governor of Papua

The main issue is whether the DPRP and the Governor of Papua has authority to take over the authority of the Election Commission in determining the registration period and verification of the local election for the Governor and Vice-Governor of Papua, except factual verification which is exercised by the Election Commission.

The Constitutional Court decided to accept the petition of the applicant. In this decision, the Constitutional Court considers regional government (the Governor and the DPRP) as the parties that have legal standing in dispute on authority among state organs. In some decisions, the Constitutional Court has considered regional government (governor and the DPRD) as the state organ that could be a subject (subjectum litis) in application of disputes on authority among state organs. This is in line with the article 24C (1) of the 1945 Constitution that states that the state organ may have legal standing in application of disputes on authority among state organs if its authority (objectum litis) meets the requirement as written in the 1945 Constitution that the organ has authority given by the Constitution ${ }^{18}$.

The Constitutional Court considered that the authority to determine the period and registration of governor election in Papua is not part of the special autonomy of Papua. Therefore, the DPRP and the Governor of Papua cannot take over the authority of the Election Commission in determining schedule and registration of governor election in Papua.

However, in the name of legal utility, the Court stated that the Election Commission must proceed the process of registration of candidate of Governor of Papua and accepted the candidates that has been registered by the DPRP and the Governor because the DPRP and the Governor has conducted some registration and verification of candidate Governor of Papua. The Court also commanded the Election Commission to extend the registration period for other candidate of Governor of Papua (in 30 days).

In this case, the Constitutional Court has shown its function as facilitator and mediator of conflict among the Election Commission, the DPRP, and the Governor. In other words, the Court has played an important role in creating a conducive

18 See also Decision No. 1/SKLN-VIII/ 2010 
political environment in the process of Governor election in Papua. It is actually part of significant contribution in consolidating democracy in the level of local election in Papua.

\subsection{Not accepted decisions due to subjectum litis}

3.3.1. Decision No. 1/SKLN-X/2012 on dispute on authority between the Minister of Home Affairs vs Election Commission and Independent Election Commission in Aceh and Governor of Aceh, Irwandi Yusuf

The main issue is whether the Minister of Home Affairs has authority to postpone the step of the local election and re-open for registration of candidacy.

The Constitutional Court decided that the Independent Election Commission of Aceh is allowed to continue the step of the local election and re-open for registration of new candidate within 7 days after the decision (Putusan Sela) is announced ${ }^{19}$. The Court argued that if the Independent Election Commission of Aceh would not extend schedule for registration of candidate, it would ignore political right of other candidates to register to be candidate of Governor. This situation would potentially disturb local election process and the working of government which produced by the local election in Aceh.

This decision shows that the Constitutional Court tries to facilitate a more conducive political situation in Aceh since Aceh is recognized as one of the provinces with unstable political situation. In term of Aceh, it is needing a very extra effort to create a better political stability after the peaceful agreement between the Central Government and the Aceh Movement for Independence (Gerakan Aceh Merdeka). In other words, at the regional level, Aceh is in the process of democratic consolidation. Therefore, giving more opportunity to the new candidate in the local election could be a way to strengthen the process of democratic consolidation in Aceh.

In the final decision, the Constitutional Court rejected the petition of the Minister of Home Affairs. The Court argued that the Minister of Home Affairs could not fulfil as the subject of the dispute because the Minister of Home Affairs might not independently be subject of dispute because the Minister of Home Affairs is part of the President Deputy which could not be the subject independently.

Through the decision, the Court repeatedly asserted that the petitioners in the disputes concerning authority among state organs must fulfil two requirements i.e. subjectum litis and objectum litis. The Court also warned the government to be more careful in bringing disputes in the Constitutional Court since the subjectum litis and objectum litis are the main important issues for the Constitutional Court in considering the disputes.

3.3.2. Decision No. 030/SKLN-IV/2006 on dispute on authority between Indonesian Broadcasting Commission (KPI) and President Republic of Indonesia qq. Minister of Communication and Information

The main point of the petition is the KPI considered that the Minister of Communication and Information has taken, reduced, prevented, and ignored the authority of the KPI as the state organ which has responsibility to issue permit and

19 Preliminary Decision (Putusan Sela) No. 108/PHPU.D-IX/2011 
make regulation on "broadcasting". As an independent commission, the KPI argued that they have responsibility in developing, enforcing and fulfilling the rights of citizen as stated in article $28 \mathrm{~F}$ of the 1945 Constitution ${ }^{20}$.

The Constitutional Court rejected the petition of the applicant because the Court argued that the KPI had no legal standing as a subject of dispute. The Court further argued that the KPI is an organ which is given the authority by the 1945 Constitution. The KPI is an organ which is given authority by the act.

3.3.3. Decision No. 002/SKLN-IV/2006 on dispute on authority between Badrul Kamal and Syihabuddin Ahmad (Candidate for Mayor in Depok, West Java) and Election Commission of Depok, West Java

The main issue is whether the Supreme Court has authority to try and decide a dispute of the result of local election in Depok which has decided final and binding the High Court of Bandung, West Java. The Supreme Court finally received the petition of Peninjauan Kembali from the Election Commission of Depok and decided Nurhmahmudi Ismail as the winner in the local election of Depok.

The Constitutional Court stated that the petition of the applicant could not be accepted (niet ontvankelijk verklaard) because the subjectum litis and objectum litis of the petition could not be fulfilled. The Court considered that KPUD Depok is not the organ which has authority from the 1945 Constitution. It has delegation authority from Regional Government Act. Therefore, the Court considered that it is not part of constitutional disputes.

Through the decision, the Constitutional Court has given an important role in creating legal certainty on the result of local election in Depok, Indonesia. By having the decision, the Court has finished a long dispute between the two candidates of Mayor in Depok which threatens the political stability in the region. Again, the Court has played positive contribution in consolidating democracy in the Depok Municipality.

\subsection{Not accepted decisions due to objectum litis}

3.4.1. Decision No. 2/SKLN-IX/2011 on dispute on authority between Andi Harahap (the Regent of Penajam Paser Utara) and Nanang Ali (the Chairman of Penajam Paser Utara) vs Minister of Forest of the Republic of Indonesia

The applicant in this case argued that they have authority in managing the wealth of the region. However, they could not exercise the authority since the Minister of Forest has prevented (obstructed, reduced and ignored). The Minister of Forest was considered as the representative of the Central Government, has ignored the existence of the new district, Penajam Paser Utara in determining Special Zone for Forest of Tanaman.

The Minister of Forest has decided through its decree that Taman Hutan Raya Bukit Soeharto which is in the District of Penajam Paser Utara, East Borneo as

20 Article $28 \mathrm{~F}$ of the 1945 Constitution states that "every person shall have the rights to communicate and to obtain information for the purpose of the development of his/herself and social environment, and shall have the rights to seek, obtain, possess, store, process and convey information by employing all available types of channels". 
Protecting Forest. However, the Governor has decided the area of housing for transmigration.

The Constitutional Court stated that the petition of the applicant could not be accepted (niet ontvankelijk verklaard). Although the applicant is considered as the subjectum litis in the Court, the Court argued that there are not constitutional disputes between the applicant and the Minister of Forest because based on the 1945 Constitution and Law No. 41 of 1999, the Central Government c.q. Minister of Forest has authority to manage and explore the natural resource for the sake of people's prosperity ${ }^{21}$.

In this decision, the Court has determined an important thing in the light of consolidating democracy i.e. the Court has accepted the position of local government as the subjectum litis in case of disputes on jurisdiction among the state organs. Admitting the subjectum litis of the local government in bringing a case to the Court is important in the light of how create more democratic, accountable and transparent policy between the Central Government and local government.

3.4.2. Decision No. 26/SKLN-V/2007 on Dispute between Election Commission of Aceh Tenggara Regency and Local Parliament of Aceh Tenggara Regency vs Independent Election Commission of Province of Aceh and the Governor of Aceh, and President Republic of Indonesia c.q. Minister of home Affairs.

The issue of this petition is the petitioners argued that the defendant I and II has taken over the authority of the petitioners in determining and issuing official document on the Result of Recapitulation of Election of Regent in Aceh Tenggara. The Constitutional Court did not accept the petition of the Petitioners because the Petitioners and Defendant I are the organs which have authority given by the laws, the Court argued that the dispute is not a dispute concerning authority among state organs as mentioned by Article 24C (1) of the 1945 Constitution, and Article 61 (1) of the Constitutional Court Act, and Article 2 (1) of the Constitutional Court Regulation No. 08/PMK/2006. In other words, the petitioners failed to fulfil objectum litis of the petition.

3.4.3. Decision No. 004/SKLN-IV/2006 on Disputes between Drs. Saleh Manaf, Regent of Bekasi Regency, West Java and Drs. Solihin Sari, Vice Regent of Bekasi Regency, West Java vs the President Republic of Indonesia, Minister of Home Affais, and Local Parliament of Bekasi Regency.

This is called as "the landmark decision of the Constitutional Court" relating to the definition of "objectum litis" which considered giving limitation to the petitioners. This limitation of objectum litis of disputes which is later on implemented by the Constitutional Court in the next decisions.

In this decision, the Court did not accept the position of the Regent and the Vice Regent as the subject of the petition because based on the objectum litis of the petition, the authority which questioned by the petitioners is not part of the authority which is given the 1945 Constitution.

21 Article 33 (3) of the 1945 Constitution and Article 4 (1) of Law No. 41 of 1999 on Forest. 
In this decision, the Court gives some requirements of the objectum litis, namely:

a. The authority of the state organs given by the Constitution (explicitly);

b. The authority could be implicitly delegated by the Constitution and further regulated by laws;

c. There is a proper and necessary correlation between the authority implicitly stated in the Constitution and the laws which further regulate the authority ${ }^{22}$.

However, in case of the Regent and Vice Regent vs President-Minister of Home Affairs-Bekasi District Parliament, the Constitutional Court argued that Article 29 to 33 of Law No. 32 of 2004 do not mention textually and implicitly or there is no a proper and necessary correlation with the main authoritative provision from the 1945 Constitution. Accordingly, article 29 to 33 of the Law No. 32 of 2004 could not be the legal basis of the petitioner as objectum litis of the petition. Therefore, the Court did not accept the petition of the petitioner.

Hence, talking about the understanding of state organ definition, the first theory is adopted from Hans Kelsen perspective about The Concept of the State Organ in his book entitled General Theory of Law and State as he explained that "whoever fulfills a function determined by the legal order is an organ". Whoever runs a function which has been regulated by a legal order is an organ. ${ }^{23}$ Based on this explanation, a state institution is not always organic. In addition, all institution that prescribed by law can also be called as state institution, as long as its functions are norm creating and/or norm applying. ${ }^{24}$

Another concept of state organ definition, according to Jimly Asshiddiqie 25 , is a substantial concept. Jimly emphasized that the narrow definition of state organ has 3 categories as follows:

1. The organs are chosen or appointed to occupy a certain position or function;

2. The function is carried out as the main authority or even legally exclusive; and

3. Because of its function, these state organs are funded by the state.

Based on the decisions, it can be analyzed that since 2003 to 2013 there are only small number of cases on disputes concerning authority among state organs registered in the Constitutional Court. Furthermore, most cases which registered to the Court were rejected or not accepted by the Court due to the issue of subjectum litis and or objectum litis. The only case that accepted by the Court is the case of Election Commission vs the DPRD and Governor of Papua. In this case, the petitioners were able to fulfil the subjectum litis and objectum litis of petition, and therefore the Court decided that Election Commission has to proceed the process of registration of candidate of Governor of Papua and accepted the candidates that has been registered by the DPRP and the Governor because the DPRP and the Governor has conducted some registration and

22 See further Decision No. 004/SKLN-IV/2006, at 90-95.

23 Raisul Muttaqien. (2006). Teori Umum Tentang Hukum dan Negara. Bandung: Nusamedia dan Nuansa, p.276-277

24 Anna Triningsih and Nuzul Qur' aini Mardiya. (2017). "Interpretation of State Institutions and Disputes of State Institution in Settlement of Disputes Authorities of State Institutions". Jurnal Konstitusi, 14(4): 785

25 Jimly Asshiddiqie. (2004). Perkembangan Ketatanegaraan Pasca Perubahan UUD 1945 dan Tantangan Pembaharuan Pendidikan Hukum Indonesia, an article which was presented on a National Seminar "Perkembangan Ketatanegaraan Pasca Perubahan UUD dan Lokakarya Pembaharuan Kurikulum Pendidikat Tinggi Hukum di Indonesia", held by Asosiasi Pengajar HTN dan HAN. Jakarta, 7th of September 2004, p.32 
verification of candidate Governor of Papua. The Court also commanded the Election Commission to extend the registration period for other candidate of Governor of Papua (in 30 days) ${ }^{26}$.

There are two main reasons behind rejection of the Constitutional Court relating to the most petitions, firstly, the petitioners failed to fulfil the requirement of being the subject of the disputes in the Constitutional Court. Regarding the subjectum litis issue, Maruarar argues that definition of subjectum litis which is confined to formalism and structural analysis on state organs has prompted the failure of the Constitutional Court in guarding the 1945 Constitution in settling disputes concerning authority among state organs as mandated by the 1945 Constitution ${ }^{27}$.

On the other hand, the Constitutional Court derived article 24C of the 1945 Constitution and article 61 of the Constitutional Court Act into article 2 (1) of Regulation No. 08/PMK/2006 which states that the state organs which may be the subject of the disputes concerning authority of state organs are:

a. The People's Representative Council;

b. The Regional Representative Council;

c. The People's Consultative Assembly;

d. President;

e. The Audit Board of Indonesia;

f. Regional Government; or

g. Any other state organs whose powers given by the 1945 Constitution.

Phrase "whose powers given by the 1945 Constitution" as stated by article 61 (1) of the Constitutional Court Act means "attributive authority" which is delegated by the 1945 Constitution, not any authority delegated by any regulations below the 1945 Constitution ${ }^{28}$. Classification of disputes as mentioned in the Article 61 (1) of the Constitutional Court consists two meanings, i.e. first, some state organs have been clearly named in the article, second, point $g$ of the article give a more facultative meaning. Which state organs beside 6 state organs that have been clearly stated in the article that have authority to bring petition to the Constitutional Court? It is not definitely answered. It leaves to the judges of the Constitutional Court to interpret the classification of other organs as mentioned in point $\mathrm{g}$.

Secondly, limitation of objectum litis which considered by the Court as the objects that the Court has authority to decide. By this limitation, some petitions are considered by the Court that there are no disputes on authority among state organs which the authority given by the 1945 Constitution. The Court argued that the disputes which would be settled by the Court are the disputes on authority among state organs whose powers given by the 1945 Constitution. However, the 1945 Constitution and the Constitutional Court Act do not give a definitive definition of the objectum litis. It is still unclear.

6 See further Decision No. 3/SKLN-X/2012.

27 See Luthfi Widagdo Eddyono, n. 418, p.33-34

28 Lukman Hakim. (2010). “Sengketa Kewenangan Kelembagaan Negara dan Penataannya dalam Kerangka Sistem Hukum Nasional". Jurnal Yustisia. 80(21), p.7 
Table 1. Requirements of Disputes on Jurisdiction among State Organs.

\begin{tabular}{|c|c|c|}
\hline No. & Position & State Organs \\
\hline 1. & $\begin{array}{l}\text { Subjectum Litis } \\
\text { (Petitioners or } \\
\text { Defendant) }\end{array}$ & $\begin{array}{l}\text { Article } 2(1) \text { of the Constitutional Court Regulation No. } \\
\text { 8/PMK/2006 states that state organs that can be petitioners } \\
\text { or defendants in disputes concerning jurisdiction among } \\
\text { state organs, i.e.: } \\
\text { a. People's Representative Council (DPR) } \\
\text { b. Regional Representative Council (DPD) } \\
\text { c. People's Consultative Assembly (MPR) } \\
\text { d. President } \\
\text { e. Audit Board } \\
\text { f. Regional Government, or } \\
\text { g. Any organs whose powers given by the } 1945 \\
\text { Constitution. }\end{array}$ \\
\hline
\end{tabular}

2. Objectum Litis

Article 2 (2) states that the jurisdiction as stated in the article (Object of Disputes) 2 (1) is the jurisdiction given by the 1945 Constitution.

Source: Constitutional Court Regulation No. 8/PMK/2006

The Constitutional Court has tried to give a further explanation on the meaning of the objectum litis through its Decision No. 004/SKLN-IV/2006. This could be named as "the landmark decision of the Constitutional Court" relating to the definition of "objectum litis" which considered giving limitation to the petitioners. This limitation of objectum litis of disputes which later implemented in the next decisions. In this decision, the Court gives some requirements of the objectum litis, namely:

a. The authority of the state organs given by the Constitution (explicitly);

b. The authority could be implicitly delegated by the Constitution and further regulated by laws;

c. There is a proper and necessary correlation between the authority implicitly stated in the Constitution and the laws which further regulate the authority. ${ }^{29}$

However, in case of the Regent and Vice Regent vs President-Minister of Home AffairsBekasi District Parliament, the Constitutional Court argued that Article 29 to 33 of Law No. 32 of 2004 do not mention textually and implicitly or there is no a proper and necessary correlation with the main authoritative provision from the 1945 Constitution. Accordingly, article 29 to 33 of the Law No. 32 of 2004 could not be the legal basis of the petitioner as objectum litis of the petition. Therefore, the Court did not accept the petition of the petitioner.

It is worthy noted that there are two judges of the Constitutional Court who gave dissenting opinion in this decision. Abdul Mukhtie Fajar, for instance, argued that the Regent/Vice Regent of District of Bekasi is one of the state organs which named in Article 18 (4) of the 1945 Constitution and they have constitutional authority as stated by Article 18 (2), (5) and (6) of the 1945 Constitution, equal to Local Parliament of Bekasi.

29 See further Decision No. 004/SKLN-IV/2006, p.90-95. 
Recognition of the Regent/Vice Regent or Mayor/Vice Mayor as part of organ which have constitutional authority implicitly could also be found in the Decision of the Constitutional Court No. 002/SKLN-IV/2006. Based on the argument, Abdul Mukhtie Fajar argued that the case brought by the Regent/Vice Regent is dispute concerning constitutional authority of the petitioners as stated in the Article 24C of (1) of the 1945 Constitution and the Constitutional Court Act. He further added that the existence of the Constitutional Court as asserted in the general explanation of the Constitutional Court Act is to maintain the working of a stable government. The action taken by President had disturbed stability of Government of Bekasi that has been run well by the petitioners in two years ${ }^{30}$.

Maruarar Siahaan also asserted that if the Constitutional Court uses a narrow or strict interpretation in settling disputes among state organ, the Court cannot uphold the Constitution. He further argued that the judges of the Constitutional Court do not be trapped into the original intent of the framers of the Constitution. He provokes judges of the Constitutional Court to response more about the dynamic progress of constitutional system and demand of the practice of the unknown future ${ }^{31}$. Relating to the petition, Maruarar argued that the petitioners are the state organs whose authority given by the 1945 Constitution although detail authority of the petitioners derivatively regulated in the law ${ }^{32}$. Maruarar proposes new definition, that is "the disputes in the constitutional system as the result of one state organ exercises its authority given by the 1945 Constitution, has abolished, created lost and disturbed other state organ's authority 33 .

In relation to this discourse, the writer agrees with these two dissenting opinions as propounded by Abdul Mukhtie Fajar and Maruarar Siahaan. Both judges are at the same points that the Constitutional Court has not to be trapped into the original intent of the 1945 Constitution relating to Article 24C (1) of the 1945 Constitution while ignoring two things, i.e. first, the existence of the Constitutional Court as asserted in the general explanation of the Constitutional Court Act is to maintain the working of a stable government. The action taken by President had disturbed stability of Government of Bekasi that has been run well by the petitioners in two years.

Second, judges of the Constitutional Court have to response more about the dynamic progress of constitutional system and demand of the practice of the unknown future. If the Court rejects the petition, there would be an ignorance of the constitutional rights of the Regent as well as the Vice-Regent or there would be also vacuum of law in settling disputes concerning authority among the state organs ${ }^{34}$.

Regarding to the dispute on authority in South Korea, there is no limitation of the state institutions dispute on authority whether it must be granted by the Constitution or not. However, the South Korean Constitutional Court Act gives a definitive state institution that have legal standing to be the party in the dispute on jurisdiction among the state

\footnotetext{
Ibid, p.103-106

Ibid, p.107

Ibid, p.110

Ibid, p.112

Maruarar argued that a break through has to be done by the Constitutional Court in order to uphold the Constitution and protect constitutional right of a regent and vice-regent from any disturbances of other organs. Maruarar further defensed that this break through is important because the Constitutional Court has no authority to decise petition regarding constitutional complaints of the citizen. Therefore, it is important to be noted that it is better for the Constitutional Court to have authority in deciding constitutional complaints in order to guarante te rights of citizen from any violations.
} 
organs. This is in contrary to Indonesian dispute settlement authority between state institutions, where the disputed authority only which is given by the Constitution. Constitutional Court of South Korea in maintaining dispute settlement on authority of state institutions can freeze the activity of state agencies were sued until the final verdict issued by the court ${ }^{35}$. As for maintaining the authority, the Constitutional Court of South Korea adopted a substantive and procedural process ${ }^{36}$.

Article 62 of the Constitutional Court Act of South Korea classifies their classification of competent disputes as Table 2.

Table 2. Classification of Subjectum Litis and Objectum Litis in South Korea

\begin{tabular}{ll}
\hline No. Position & State Organs \\
\hline 1. Subjectum & $\begin{array}{l}\text { Article } 62 \text { of the Constitutional Court Act classifies some types of } \\
\text { competent disputes, i.e.: } \\
\text { 1. Disputes between state agencies: National Assembly, The } \\
\text { Executive, ordinary courts, and the National Election } \\
\text { Commission. }\end{array}$ \\
2. Disputes between a state agency and a local government: \\
a. Between the Executive and the Special Metropolitan City, \\
Metropolitan City or Province; and \\
b. Between the Executive and the City/County or District \\
which is a local government (Self-governing District) \\
3isputes between local governments: \\
a. Between the Special Metropolitan City, Metropolitan City \\
or Province; \\
b. Between the City/County or Self-governing District;
\end{tabular}

2. Objectum Litis Competent Disputes

Source: South Korean Constitutional Court Act

1. Adjudication on competence disputes between state agencies: adjudication on competent dispute between the National Assembly, the Executive, ordinary courts and the National Election Commission;

2. Adjudication on competence dispute between a state agency and a local government:

a) Adjudication on competence dispute between the executive and the Special Metropolitan City, Metropolitan City or Province; and

b) Adjudication on competence dispute between the Executive and the City/County or District which is a local government (hereinafter referred to as a "Self-governing District").

35 Muchamad Ali Safa'at, et.al. (2010). Hukum Acara Mahkamah Konstitusi. Jakarta: Sekretariat Jenderal Mahkamah Konstitusi Republik Indonesia in cooperation with Assosiasi Pengajar Hukum Acara Mahkamah Konstitusi, p.154

36 Jibong Lim. (2006). "Korean Constitutional Court and Due Process Clause". Journal of Korean Law, 6(1): 11 
3. Adjudication on competence dispute between local governments:

a) Adjudication on competence dispute between the Special Metropolitan City, Metropolitan City or Province;

b) Adjudication on competence dispute between the City/County or Selfgoverning District; and

c) Adjudication on competence dispute between the Special Metropolitan City, Metropolitan City or Province and the City, County, or Self-governing District.

In addition, the Constitutional Court failed to understand the significant changes of the state organs in Indonesia after four amendments of the 1945 Constitution. One of the significant changes is the shifting of state organ's paradigm which is called by Jimly Asshiddiqie from vertical -hierarchical to horizontal-equal among state organ and the emergence of new state auxiliary organs ${ }^{37}$ such as Judicial Commission, Election Commission, Anti-Corruption Commission, Ombudsman Commission etc. However, even after amendments of the 1945 Constitution, the 1945 Constitution does not explain clearly the concept of state organ.

In 1997, at least there were around 21 non-governmental institutions and 31 extrastructural institutions under the President as well as the ministers. After the political reform in 1998, there are more state agencies which are established by the President or by laws ${ }^{38}$. In this context, there is a question whether normative sources of authority of the state agencies are automatically determine its legal status in the hierarchy of state organs ${ }^{39}$ and implies on its legal standing in the Constitutional Court as the subject.

The explanation of other state organs which are given authority by the 1945 Constitution as the subject of the disputes shows that the applicants are not only the previous state organs that are clearly stated, but there are also other state organs. The extensive meaning of the state organs is also asserted by the Decision of the Constitutional Court No. 004/SKLN-IV/2006 on12 July 2006 which states "in determining the substance and limitation of authority which could be objectum litis of dispute on authority of state organs, the Constitutional Court does not merely interpret through textual approach on the text of the provisions in the 1945 Constitution, but the Constitutional Court also considers any possibilities of implicit authority in particular main authority or necessary and proper authority in exercising of the main authority ${ }^{40}$.

On the other hand, according to Jimly Asshiddiqie, there are 28 state organs that are explicitly and implicitly recognized in the 1945 Constitution. The authority of these state organs, however, are regulated in different types of legislation such as it is clearly stated

37 Zainal Arifin Mochtar stated in his conclusion of the thesis that after the 1998 political reform, there is a new trend in Indonesia, that is a inflation of state auxiliary organs. Although it is a common trends in many countries, in Indonesia, there is no clear and intergrated plan in establishing the state auxiliary organs. Therefore, he proposes reposition or restructurization of the state auxiliary organs is needed. See further Zainal Arifin Mochtar, n. 408, p.91

38 Zainal Arifin Mochtar, n. 408, p.2-3

39 Lukman Hakim. (2010). “Sengketa Kewenangan Kelembagaan Negara dan Penataannya Dalam Kerangka Sistem Hukum Nasional". Jurnal Hukum Justicia Fakultas Hukum Universitas Sebelas Maret Surakarta. 80

40 Lukman Hakim, n. 414, p.82. 
in the 1945 Constitution or it is further regulated in laws. These are the state organs as follow: 41

1. People's Consultative Assembly (Majelis Permusyawaratan Rakyat/MPR),

2. House of Representatives (Dewan Perwakilan Rakyat/DPR),

3. Regional Repesentative Council (Dewan Perwakilan Daerah/DPD),

4. $\quad$ President and Vice-President (Presiden and Wakil Presiden)

5. Advisory Council of President (Dewan Pertimbangan Presiden)

6. Ministries (Kementerian Negara)

7. Ambassadors (Duta)

8. Counsel (Konsul)

9. Provincial Government (Governor and the Regional House of Representative)

10. District Government (Regent and the Regional House of Representative)

11. Municipality Government (Mayor and the Regional House of Representative)

12. Election Commission (Komisi Pemilihan Umum/KPU)

13. Central Bank (Bank Sentral)

14. Supreme Audit Boadr (Badan Pemeriksa Keuangan/BPK)

15. Supreme Court (Mahkamah Agung/MA)

16. Constitutional Court (Mahkamah Konstitusi/MK)

17. Judicial Commission (Komisi Yudisial/KY)

18. National Army (Tentara Nasional Indonesia/TNI)

19. Police (Kepolisian Negara Republik Indonesia)

20. Special Autonomy Government (Pemerintah Daerah Khusus or Istimewa)

21. Unity of Communities Based on Adat Law (Kesatuan Masyarakat Hukum Adat)

So far, the Constitutional Court's decisions have been very consistent in determining state institutions that can become an applicants or defendants in resolving the dispute on authority of state institutions refer to 2 conditions of Subjectum Litis and Objectum Litis. Both conditions are applied in absolute cumulative terms, not choices. In short, even if the Subjectum Litis is fulfilled, but the Objectum Litis is not, then, the petition is always "rejected" 42 . However, it becomes a problem when these 2 conditions turn to be a hindrance for petitioners.

Having this strict definition of the state organs, therefore, it is hard for petitioners to fulfil the legal standing in the Constitutional Court. Zainal Arifin Mochtar added that limitation of state organs which made by the Court has resulted small number of cases brought to the Court. In fact, he further argues that after the political reform in 1998, there are many new state organs which are stated in the Constitution that exist and exercise the interests of the citizens such as Anti-Corruption Commission, Human Right Commission, Broadcasting Commission. Hence, Zainal asserts that in term of settling disputes concerning authority of state organs, the Court does not yet take significant role in consolidating democracy in Indonesia. 43

41 Jimly Asshidiqie. (2006). Sengketa Kewenangan Konstitusional Lembaga Negara. Jakarta: Konstitusi Press \& PT Syaamil Cipta Media, p.15

42 Sulistiya Eka Lestari. (2014). "Penyelesaian Sengketa Kewenangan Antar Lembaga Negara Oleh Mahkamah Konstitusi". Jurnal Ilmu Hukum, 10(19): 45

43 Interview with Dr. Zainal Arifin Mochtar, a constitutional law expert from Gadjah Mada University, Yogyakarta, Indonesia, June 2nd, 2014. 
4. Achievements of the Constitutional Court in the Consolidating of Democracy through Settlement of Disputes concerning Jurisdiction among State Organs

From the foregoing passages on the above decisions, it may draw some relevant points that the Constitutional Court has given contribution to the consolidation of democracy through its decisions. However, due to small numbers of cases registered, Constitutional Court had not taken significant role in settling disputes among state organs. Some achievements could be noted as follows:

(i) Constitutional Court has successfully played as a state mediator or a facilitator for any disputes concerning jurisdiction of state organs. Some decisions have been made in settling disputes concerning jurisdiction among state organs. This function is important because the members of the DPR are sometimes enacted laws which lead conflicts among state organs. In addition, a state organ also may issue decree which disturb other state organs' authorities.

(ii) Based on the decisions, it can be noted that the Constitutional Court has given its contribution in keeping balance of powers between the President and the DPR. In this case, the Court argues that approval of the DPR is compulsory because it is kind of checks and balances mechanism that has to be prevailed in the constitutional democratic state. In other words, through this decision, the Constitutional Court has significant role in consolidating democracy in Indonesia.

(iii) The Constitutional Court, through its decisions, has also played an important role in creating a conducive political environment in the process of Governor election in some regions such as Papua, Aceh and Depok. It is part of significant contribution in consolidating democracy in the level of local election in some regions.

Through the decisions, the Constitutional Court has given an important role in creating legal certainty on the result of local election in Depok, Indonesia. By having the decision, the Court has finished a long dispute between the two candidates of Mayor in Depok which threatens the political stability in the region. Again, the Court has played positive contribution in consolidating democracy in the Depok Municipality

(iv) The Court has also determined an important thing in the light of consolidating democracy i.e. the Court has accepted the position of local government as the subjectum litis in case of disputes on jurisdiction among the state organs as happened in Decision No. 2/SKLN-IX/2011 on dispute on authority between Andi Harahap (the Regent of Penajam Paser Utara) and Nanang Ali (the Chairman of Penajam Paser Utara) vs Minister of Forest of the Republic of Indonesia. Admitting the subjectum litis of the local government in bringing a case to the Court is important in the light of how create more democratic, accountable and transparent policy between the Central Government and local government.

\section{Problems Facing the Settlement of Disputes concerning the Conflict of Jurisdiction among State Organs}

Ahmad Roestandi, ${ }^{44}$ a former judge at the Constitutional Court, explains that in the 1945 Constitution (after amendments), it does not elaborate in detail the meaning of state organs and which state organs that have legal standing to bring petition to the

44 Luthfi Widagdo Eddyono. (2010). “Penyelesaian Sengketa Kewenangan Lembaga Negara oleh Mahkamah Konstitusi". Jurnal Konstitusi. 7(3), p.19 
Constitutional Court. He further considers there are only 30 state organs that named or given authority by the Constitutional Court, namely MPR, DPR, DPD, BPK, President, Vice President, Ministers, National Army, Council of Advisors of the President, Ambassador, Consul, Election Commission, Central of Bank, the Supreme Court, the Constitutional Court, the Judicial Commission, any other bodies related to the judiciary, such Attorney General, Provinces, Governor, Provincial Parliament, District Government, District Parliament, Municipality, Mayor, Municipality Parliament, Special Local Government, Adat Society, and the political party ${ }^{45}$.

Abdul Mukhtie Fajar, another former judge at the Constitutional Court further argues that since the 1945 Constitution and Constitutional Court Act 2004 do not explain the meaning and the scope of state organs, it has resulted some interpretations among judges and scholars. He categorizes three kinds of interpretation i.e. first, wide interpretation which means every state organ which are named in the 1945 Constitution. Second, moderate interpretation which confines state organs that are recognized as the highest state organs (MPR) and high state organs (President, DPR, DPD, BPK, MA and MK). Third, narrow interpretation which assumes the subject of disputes only are DPR, DPD and President (interpretation of Article 67 of the Constitutional Court Act) ${ }^{46}$.

Jimly Asshiddiqie elaborates that at least, there are 34 state organs that named the existence in the 1945 Constitution. Compared to Achmad Roestandi, Jimly derives some state organs into more detail categories such Ministers and National Army ${ }^{47}$. These show that there is different interpretation among scholars and former judges on what are the state organs that may have legal standing to bring dispute to the Constitutional Court.

Secondly, lack of understanding of the meaning of constitutional disputes on jurisdiction among petitioners that implies most petitioners tend to use judicial review although it is a constitutional dispute on jurisdiction. Jimly Asshiddiqie argues in his book that in fact there are some constitutional disputes state organs. However, the parties did not use constitutional disputes to settle the issues. Jimly Asshiddiqie gives some examples i.e. disputes between South Celebes Province and Central Government on burdening them to provide two years budget for a new province, West Celebes ${ }^{48}$. Another case is the judicial review of Law No. 4 of 2004 on Judiciary and Law No. 22 of 2004 on Judicial Commission ${ }^{49}$. This judicial review is basically disputes concerning authority among the Supreme Court and Judicial Commission.

45 Ibid, p.20-22

$46 \mathrm{Ibid}$, p.20. In his opinion, if it is used wide interpretation, there are aroung 13 state organs i.e. MPR, President, DPR, DPD, MA, MK, Central Bank of Indonesia, KPU, Regional Government, Judicial Commission, BPK, TNI and Police. In term of using moderate interpretation, there are only 7 state organs i.e. MPR, President, DPR, DPD, BPK, MA and MK. In a narrow interpretation, there are only 3 state organs i.e. DPR, DPD and the President. However, some scholars Ahmad Roestandi and Jimly Asshiddiqie) also have different opinion on numbers of the state organs which have legal standin to bring petitions to the Constitutional Court. These different opinions assert that the meaning and scope of state organ are unclear, even among judges at the Constitutional Court.

47 See Jimly Asshiddiqie. (2010). Perkembangan dan Konsolidasi Lembaga Negara Pasca Reformasi. Jakarta: Sekretariat Jenderal dan Kepaniteraan Mahkamah Konstitusi RI, p.57-59

48 Jimly Asshiddiqie. n. 39, p.19

49 See further The Constitutional Court of Republic of Indonesia Decision No. 005/PUU-IV/2006. In this decision, the judges of the Supreme Court argued that the Judicial Commission has taken over their authority in supervising the judges. The Constitutional Court nullified the authority of the Judicial Commission in supervising the judges because the Court considered that both laws has brought about legal uncertainty. 
Jimly Asshiddiqie further explains that at the beginning, when the framer's intent formulated constitutional disputes, they did not imagine that there would be constitutional disputes between provinces and the central government because they assumed that those kinds of constitutional disputes were not relevant in unitary states. That happens usually in federal state system where the states have their own independent position in the country.

Thirdly, limitation of subjectum litis and lack of understanding of objectum litis have implied that the Constitutional Court could not take maximum role in resolving disputes on jurisdiction among state organs. This opinion stated by Maruara Siahaan, a former judge at the Constitutional Court. He argues that the Constitutional Court needs to extend the meaning and scope of state organs to response current issues among the state organs. ${ }^{50}$

\section{Conclusion}

From the foregoing analysis on some decisions of the Constitutional Court concerning disputes over jurisdiction among state organs that have been discussed previously, it may sum up some conclusion that firstly, the Constitutional Court has played a limited role in settling disputes concerning constitutional authority among state organs. This is because the small number of cases that registered to the Constitutional Court. In addition, there is lack of understanding of the citizens as well as the state organs on the subjectum litis and objectum litis of the petition pertaining to dispute over the jurisdiction among state organs.

Secondly, however some achievements must be highly noted that through some decisions, the Constitutional Court have given contribution in consolidating democracy by keeping the working of checks and balances mechanism among state organs. Decision No. 1/SKLN-X/2012, Decision No.2/SKLN-X/2012 and Decision No. 3/SKLN-X/2012 could be some examples.

Thirdly, since it still has unclear concept of subjectum litis and objectum litis among petitioners, there were many petitions were not accepted. Lack of understanding of this subjectum litis and objectum litis also influence number of petitions that brought to the Constitutional Court. Therefore, the Constitutional Court Act has to define clearly classification of subjectum litis and objectum litis of the dispute. In this context, amendment of the Constitutional Court Act is also needed.

\section{References}

Books

Bambang Sutiyoso. (2009). Tata Cara Penyelesaian Sengketa di Lingkungan Mahkamah Konstitusi. Yogyakarta: UII Press.

Benny K. Harman. Peranan Mahkamah Konstitusi dalam Reformasi Hukum dari buku Menjaga Denyut Nadi Konstitusi: Refleksi Satu Tahun Mahkamah Konstitusi. Jakarta: Konstitusi Press.

$50 \quad$ Ibid, p.38-39 
Jimly Asshidiqie. (2006). Sengketa Kewenangan Konstitusional Lembaga Negara. Jakarta: Konstitusi Press \& PT Syaamil Cipta Media.

Muchamad Ali Safa'at, et.al. (2010). Hukum Acara Mahkamah Konstitusi. Jakarta: Sekretariat Jenderal Mahkamah Konstitusi Republik Indonesia in cooperation with Assosiasi Pengajar Hukum Acara Mahkamah Konstitusi.

Raisul Muttaqien. (2006). Teori Umum Tentang Hukum dan Negara. Bandung: Nusamedia dan Nuansa.

\section{Journals}

Anna Triningsih and Nuzul Qur'aini Mardiya. (2017). “Interpretation of State Institutions and Disputes of State Institution in Settlement of Disputes Authorities of State Institutions". Jurnal Konstitusi, 14(4): 785

Anna Triningsih and Nuzul Qur'aini Mardiya. (2017). “An Analysis of Subjectum Litis and Objectum Litis on Dispute About the Authority of the State Institution from the Verdicts of the Constitutional Court". Constitutional Review, 3(2): 233

Janpatar Simamora. (2015). "Comparison of Constitutional Court Authority Between Indonesia and South Korea". Jurnal Dinamika Hukum, 15(3): 331-332

Jibong Lim. (2006). "Korean Constitutional Court and Due Process Clause". Journal of Korean Law, 6(1): 11

Lukman Hakim. (2010). "Sengketa Kewenangan Kelembagaan Negara dan Penataannya dalam Kerangka Sistem Hukum Nasional". Jurnal Yustisia. 80(21): 7

Luthfi Widagdo Eddyono. (2018). "The Constitutional Court and Consolidation of Democracy in Indonesia". Jurnal Konstitusi, 15(1): 9

Luthfi Widagdo Eddyono. (2010). “Penyelesaian Sengketa Kewenangan Lembaga Negara". Jurnal Konstitusi, 7(3): 19

Lutu Dwi Prastanta. (2011). “Mahkamah Konstitusi dan Prinsip Judicial Independence dalam Sengketa Antar Lembaga Negara". Jurnal Konstitusi, 4(2): 9

Ni'matul Huda. (2017). "Potensi Sengketa Kewenangan Lembaga Negara dan Penyelesaiannya di Mahkamah Konstitusi". Jurnal Hukum Ius Quia Iustum, 24(2): 194195

Sulistiya Eka Lestari. (2014). "Penyelesaian Sengketa Kewenangan Antar Lembaga Negara oleh Mahkamah Konstitusi". Jurnal Ilmu Hukum, 10(19): 45

\section{Reports}

Asshiddiqie, Jimly, (2010). Perkembangan dan Konsolidasi Lembaga Negara Pasca Reformasi. Jakarta: Sekretariat Jenderal dan Kepaniteraan Mahkamah Konstitusi RI.

Mochtar, Zainal Arifin, (2012). Penataan Lembaga Negara Independen Setelah Perubahan Undang-Undang Dasar 1945. A summary of Ph.D Thesis. Universitas Gadjah Mada.

Butt, Simon and Tim Lindsey, (2009). The People's Prosperity? Indonesian Constitutional Interpretation, Economic Reform, and Globalization, in John Gillespie E Randall Peerenboom (Eds), Regulation in Asia-Pushing Back on Globalization, London and New York: Routledge. 
Hazama, (2009). Constitutional Review and Democratic Consolidation: A Literature Review. A Paper presented at IDE Discussion Paper, Japan.

Websites

Indonesian Constitutional Court, Rekapitulasi Perkara Sengketa Kewenangan Lembaga Negara. Available from: https://mkri.id/index.php?page=web.RekapSKLN. [Accessed: 7 March 2013].

\section{Conflict of Interest Statement:}

The author(s) declares that the research was conducted in the absence of any commercial or financial relationships that could be construed as a potential conflict of interest.

Copyright $\odot 2019$ HALREV. All rights reserved. 